\title{
Adalet Hizmetlerinde Beklenti Çıpası ve Beklenti Yanlışlaması Hipotezleri: Türkiye Örneği ${ }^{*}$
}

\author{
Sevilay Ece GÜMÜŞ ÖZUYAR ${ }^{* *}$, Alparslan A. BAŞARAN ${ }^{* * *}$, Necmiddin BAĞDADİOĞLU $^{* * * *}$
}

ÖZ

Kamu kurumlarının daha birey merkezli ve piyasa koşullarına daha uygun hale getirilmesi amacıyla yeni kamu politikaları uygulanmaktadır. Bu politikalarda vatandaşların istek ve ihtiyaçlarını tatmin edecek doğru çıktıların sunulabilmesi amacıyla yine vatandaşların mal ve hizmetlere yönelik tercih ve talepleri belirlenmeye çalışılmaktadır. Hizmetlerin sunulduğu ülkede yaşayan bireylerin sosyo-ekonomik ve sosyo-demografik unsurlarının iyi belirlenmesi, performans göstergelerinin bu unsurlar çerçevesinde şekillendirilmesi gerekmektedir. Beklenti yanlışlaması ve beklenti çıpası yöntemleri bireylerin kamu hizmetlerden memnuniyetleri ile hizmet sunucunun performansına dair çözümlemeler sunmaktadır. Bu çalışmada TÜİK 2012 Yaşam Memnuniyeti Anket verileri kullanılarak Türkiye'de beklenti yanlışlama ve beklenti çıpası savları adalet hizmetleri özelinde test edilmiştir. 2012 yılı TÜIKK tarafindan Türkiye genelinde bu anketin uygulandığı son sene olması maksadıyla seçilmiştir. Bulgulara göre, Türkiye için her iki hipotezin de geçerli olduğu saptanmış ve analizler sonucunda Türk adalet hizmeti kullanıcılarının memnuniyet bazlı talep profilleri de çıkarılmıştır.

Anahtar Kelimeler: Memnuniyet, Beklenti çıpası, Beklenti yanlışlaması, Performans, Kamu hizmetleri JEL Sınıflandırması: D12, H11, H41, H61, J11, J18

\section{Expectation Anchoring and Expectation Disconfirmation Hypotheses of Judicial Services: The Case of Turkey}

\begin{abstract}
New public policies are implemented to make institutions more citizen-centered and more relevant to market conditions. With these policies, preferences and demands of citizens for public goods/services are tried to be determined to provide correct outputs that will satisfy desires and needs of citizens. So, socio-economic and sociodemographic elements of the residents where the services are provided should be well defined and the performance indicators should be shaped within this framework. Expectation anchoring and expectation disconfirmation hypotheses provide resolutions on individuals' satisfaction from public services and the performance of the service provider. Our aim is to test the validity and the accuracy of both hypotheses for judicial services using TURKSTAT 2012 Life-Satisfaction-Survey data. 2012 is selected since it was the last year conducted at the national level. Accordingly, it is determined that the both hypotheses are valid, and satisfaction-based demand profiles of Turkish justice services consumers are obtained.
\end{abstract}

Keywords: Satisfaction, Expectation Anchoring, Expectation Disconfirmation, Performance, Public Goods

JEL Classification: D12, H11, H41, H61, J11, J18

Geliş Tarihi / Received: 10.08.2019 Kabul Tarihi / Accepted: 28.11.2019

\footnotetext{
* Bu çalışma, “Türkiye'de Adalet Hizmetleri Talebinin Belirleyicileri: Yaşam Memnuniyeti Yöntemi ile Bir Uygulama 2004-2012” isimli tez çalışmasından türetilmiştir.

** Arş. Gör. Dr., Uşak Üniversitesi, İIBF, Maliye Bölümü, sevilay.gumus@usak.edu.tr, ORCID: 0000-0002-19573648.

*** Doç. Dr., Hacettepe Üniversitesi, İ̈BF, Maliye Bölümü, aab@hacettepe.edu.tr, ORCID: 0000-0003-1027-8375.

**** Prof. Dr., Hacettepe Üniversitesi, İİBF, Maliye Bölümü, necbag@hacettepe.edu.tr, ORCID: 0000-0002-69285273.
} 


\section{GíRiş}

İktisadi literatürde bireylerin tercihte bulunurken memnuniyet/mutluluk düzeylerini arttıracak tercihlerde bulunduğu, faydanın da bu memnuniyet/tatmin olgusundan türeyen bir olgu olduğu artık genel geçer bir kabul niteliğindendir (Baujard, 2013; Bentham, 2000; Hausman \& McPherson, 1997; Mill, 2008; Urmson, 1953). Bentham (2000: 19-21), bireyin memnuniyetini/ hazzını temel almadan yapılan tüm ölçümlerin insanları zevklerinden uzaklaşmış bir sofu düzeyinde incelemek olduğu, dolayısı ile böyle bir yönetiminin de başarısız olacağını savunmaktadır. Ayrıca bireylerin memnuniyetini/mutluluğunu arttıran faydanın ölçümü yalnızca bireyin içselliği için değil, toplumun genel refahını tahlil edebilmek için de önemlidir. Çünkü bireysel faydaların toplamı ile toplumsal refaha ulaşılabilmektedir ve devlet, birey ve toplum arasındaki memnuniyet-fayda ilişkisinin düzenli işleyişinin sağlanması ve piyasanın başarısızlığa uğradığ1 savaş gibi olağanüstü durumların finanse edilmesi noktasında gerekli bir mekanizmadır (Bentham, 1954: 429; Bentham, 1795: 40; Bentham, 2000: 28). Yani devletin görevi, bu refahın verdiği hazzı arttırmanın yanı sıra mali, hukuki, askeri ve kolluk gücü (polis) açısından refah ve memnuniyetleri güvence altına almaktır (Bentham, 1795: 41).

$\mathrm{Bu}$ noktada devletin güvence altına alma yükümlülüğü bulunan vatandaşların memnuniyetlerini etkileyen unsurlar ile ilgili literatürde çok sayıda araştırma bulmak mümkündür (ör. Folz, 1996; Miller \& Miller 1991; Parasuman vd., 1988; Swindell \& Kelly, 2000; Webb \& Harry, 1973). Özel mal ve hizmetler ile birey memnuniyeti arasındaki ilişkinin bir benzerinin hizmet sunucusu devlet ile bu hizmetleri kullanan vatandaşlar arasında kurulması ise son birkaç on yıldır kamusal mal ve hizmetler aracılığıly yapılmaktadır. Örneğin belediye hizmetlerinin kalite ve sunumlarının iyileştirilmesi açısından bu hizmetleri tüketenlerin memnuniyet algılarına yönelik çalışmalarına literatürde sıklıkla rastlanır. ABD (DeHoog vd, 1990; Montalvo, 2009), Avrupa ve Orta Asya (Diagne vd., 2012), Uzak Doğu Asya ve Çin (Abdullah\& Kaliannan, 2008; Ma, 2016) gibi dünyanın birçok ülkesinde ve bölgesinde belediye hizmetlerinden vatandaş memnuniyeti ve bu durumun hizmet yönetimine etkisi politika uygulamalarında kullanılmaktadır. Stipak (1980: 523) yerel nitelikte belediyeler tarafindan sunulan kamusal hizmetlerin kalitesini arttırmak için hizmetlerden memnuniyete odaklanırken, Dayton, Ohio (ABD)'un 1974 yllından bu yana yıllık olarak vatandaş memnuniyet anketleri ile yönetimini güncellediğine değinmiştir. 2000 yılında Avusturalya'nın South Perk şehrinde 15,000 hane halkı ile yapılan toplu taşımacılıktan memnuniyet anketi bu şehirdeki hizmet kalitesinin ölçütü olarak kullanılmış ve kamu taşımacılığında iyileştirmeler için anket sonuçları doğrultusunda politikalar geliştirilmiştir (Blaug vd, 2006: 64). Amerika Birleşik Devletleri Muhasebe Standartları Kurulu (GASB) gönüllü olarak performans bilgilerinin elde edilmesinde ve hizmet kalitesinin bu bilgiler 1şı̆̆ında iyileştirilmesinde; Amerika Kurtarma ve Yeniden Yatırım Yasası (ARRA) özellikle işlerin/memuriyetlerin yeniden tasarlanması veya dağıtılmasında; Performans Ölçüm Merkezi (ICMA-CPM) New York şehrinde olduğu gibi bölgesel performans değerlendirmelerinin yapılması sırasında ve diğer yönetimlerin istatistiksel performans ölçüm sistemlerinde memnuniyet kavramını ve memnuniyet ölçümü için yapılan anketleri değerlendirmeye almıştır (Steinberg, 2009: 5).

Bu noktada özel sektördeki "müşteri” odaklı anlayışının kamu sektörünün hedef ve amaçlarına uygun hareket edebilmesi ve bu hedef ve amaçlara hangi seviyede ulaşılabildiğinin tespit edilebilmesi için objektif ve anlaşılabilir ölçütler kullanılması ve ölçümler yapılması gereklidir. Bu ölçümlerin hareket noktası da, kamu kesiminin organizasyonunu belirleyen, performanstır (Akgül, 2003: 12; Çoban \& Deyneli, 2005: 10).

Performans, etkin ve etkili sonuçlara ulaşılıp ulaşılamadığı ile ilgili olarak bir durumun bir önceki duruma nazaran değişimi anlamına gelmektedir ve geçmiş sonuçlara ya da öngörülen çıktılara göre ölçülmektedir (Brumby vd., 2010: 42). Bu ölçüm hem kamu hizmetlerinin kalitesinin arttırılmasının yanı sıra hesap verebilirliğin etkin bir şekilde gerçekleştirilmesini de 
sağlamaktadır (Yenice, 2006: 58). Önceden tespit edilmiş hedeflere ulaşırken var olan kaynakların nasıl değerlendirildiği sorusuna yanıt veren performans ölçümü, performans ölçüleri ve göstergeleri aracılığı ile sağlanmaktadır ve verimlilik, hizmet kalitesi, vatandaş memnuniyeti gibi unsurları yakından ilgilendirmektedir (Akçakaya, 2012: 172).

Performansa ilişkin bir başarı değerlendirmesi yapabilmek için bir hizmetin ya da programın geçmiş performansının bugün ve gelecek ile ilişsisinin kurulması bir zorunluluktur. Bu noktada bir ürünün ya da hizmetin bunları kullanacak olan tüketiciyi gelecekte tam olarak memnun edip etmeyeceği beklentilerle açıklanmaktadır (Swan \& Travick,1980: 8). Hizmetlerin değerlendirilmesi, bütçe tahsisatlarının, operasyonel süreçlerin, hizmetlerin yapısının değiştirilmesi gibi birçok yönetsel kararın alınabilmesi için memnuniyet ölçütleri kullanıldığından beklentilerin rolü önemlidir (James, 2009: 108). Bir başka deyişle beklenti ve vatandaş memnuniyeti "performansin anlaşılabilmesi için bir standart noktası" (Wilson vd., 2008: 55) veya mukayeseli bir analiz için gerekli mihenktir (Oliver, 1980: 460). Memnuniyet, beklenti ve performans arasındaki üçlü ilişkiyi değerlendiren temel unsurlar ise beklenti çıpası ve beklenti yanlışlaması hipotezleridir.

Bu minvalde bu çalışmanın amacı beklenti yanlışlaması ve beklenti çıpası hipotezlerinin Türkiye örneğinde tam kamusal mal ve hizmet grubundan olan adalet hizmeti açısından test edilmesidir. Dolayısı ile çalışma şu şekilde yapılandırılmıştır: Birinci bölümde yanı sıra beklenti çıpası ve beklenti yanlışlaması başlığı altında beklenti ve memnuniyet arasındaki ilişki ile birlikte başlığa konu olan iki hipotezde açılanacaktır. Takip eden bölümde (Veri, Metodoloji ve Bulgular kısmında) ise Türkiye İstatistik Kurumu (TÜIK) 2012 yılı Yaşam Memnuniyeti Anket sonuçları kullanılarak analizler gerçekleştirilecek, analiz sonuçları tartışılacaktır. Sonuç ve Öneriler başlığını taşıyan son bölümde ise yaşam memnuniyeti yöntemi kullanılarak Türkiye'de yaşayan 18-99 yaş arası yetişkin bireylerin bir tam kamusal mal olan adalet hizmetine yönelik algılarından yola çıkarak gelecekte memnuniyet konusunda yapılacak çalışmaların kamu politikalarını nasıl şekillendireceği ve hükümetlerin bu yöntemi kullanmak suretiyle elde ettikleri vatandaşların hükümetin mal-hizmet sunum performansı hakkında düşünceleri gibi bilgileri nasıl kullanabilecekleri konusunda değerlendirmelerde bulunulacaktır.

\section{BEKLENTI ÇIPASI VE BEKLENTI Y YNLIŞLAMASI}

Özel sektör pratiklerinin kamu sektörü yönetimine adapte edilmesi, kamuda işletmecilik anlayışııın oluşmasına sebep olmuş (Millward \& Proven, 2000: 372) ve geleneksel refah devlet anlayışı "sözleşmeci" devlet (Rathgerb \& Lipsky, 1993: 21-22) ya da başka bir ifade ile "girişimci devlet"e (Farazmand, 1997) dönüşmüştür. Bu anlayışta, devlet "Kürek çekmekten çok, dümen tutmaktadır" ve rekabeti geliştirici, vatandaşı bir müşteri olarak gören, vatandaşı güçlendirici piyasa kurallarını öne çıkaran bir rol üstlenmektedir (Osborne \& Gaebler, 1993: 1920). Ayrıca vatandaşa yardımcı olan, bireysel ve toplumsal çıkarları temel alan, politikalar geliştirirken vatandaşı da sürece dâhil eden bir şekilde hizmet sunmaktadır (Denhardt \& Denhardt, 2000: 554-556). Dolayısıyla bireyler, hane halkları, özel işletmeler ve sivil toplum örgütlerinden oluşan bir yapının kamusal mal ve hizmet sunumunda devlet ile beraber yer alması düşüncesi, çıktı temelli ve müş̧eri odaklı bir yaklaşımın benimsenmesi sonucunu doğurmuştur (Robertson \& Ball, 2002: 387). Böylece tekel konumundaki kamu hizmeti sağlayıcılarının özel sektör şartlarındaymış gibi faaliyet gösteren, rekabetçi ya da yarı-özel hizmet sağlayıcılar haline getirilmesi amaçlanmıştır (Jilke \& Van de Walle, 2013: 466).

$\mathrm{Bu}$ anlayış, kamu hizmetlerinde sürekli iyileştirme, toplam katılım ve toplumsal sorumluluk (Şimşek, 2001: 99-100) boyutlarını da içerdiğinden vatandaş sadece vergisini ödeyen pasif bir unsur olmaktan çıkartılarak kullandığı hizmetlerin üretim sürecinden dağıtım ve değerlendirmesine kadar etkili bir unsur haline getirilmiştir. Dolayısıyla vatandaşın edilgen 
durumdan etken konuma geçmesi (Eren, 2003: 66) ile bu yaklaşımı benimseyen kuruluşa yüksek kalite, üretkenlik ve rekabet gücü kazandırmış olur (Peker, 1995: 64).

Kamu sektörünün amaçladığı noktaya ulaşıp ulaşmadığının tespit edilebilmesi için objektif ve doğru ölçümler yapılması gereklidir, ki daha önce belirtildiği üzere buradaki temel etken de performanstır. Hizmet performansın doğru değerlendirilebilmesi içinse geçmiş ve gelecek arasında bir köprü kurulabilmelidir. Bu noktada da gelecekte istenileni temsil eden beklentiler önem kazanmaktadır. Birey memnuniyet, beklenti ve hizmet performansı arasındaki ilişkiyi ise bu çalışmanın test konusunu oluşturan beklenti çıpası ve yanlışmaası hipotezleri oluşturmaktadır.

Beklenti çıpası (expectation anchoring) hipotezi, bireylerin mal ve hizmetlere yönelik memnuniyetlerinin, beklentileri tarafından doğrudan etkilendiği ve yüksek hizmet sunumu beklentilerinin, memnuniyetle ters orantılı olduğu varsayımları üzerine kurgulanmıştır (Van Raaij, 1989: 474). Beklenti yanlışlaması hipotezi (expectation disconfirmation) ise satın alma ya da tüketim sonrası memnuniyetin bir fonksiyonu olarak, beklentileri ve bireylerin algıladıkları hizmet performansını değerlendirmektir. Bireylerin mal sunum memnuniyeti ve beklentileri arasında ne tür bir ilişki olduğunu araştıran bu hipotezde; bireylerin, mal ya da hizmetin kendilerinin beklediği gibi olduğunu düşündükleri durumlarda beklentilerinin karşılanmasına bağlı olarak pozitif yanlışlama; bekledikleri gibi bir sunum ya da miktar performansı gösteremediğini düşündükleri durumlarda ise negatif yanlışlama ilişkisinin varlığının tespit edileceği öngörülmektedir (Oliver, 1980: 460).

Beklenti yanlışlama hipotezine göre, tüm hizmet çeşitleri için memnuniyet ile performans eksi memnuniyet arasında pozitif bir ilişki olduğu varsayılmaktadır. Bir başka deyiş ile performans eksi memnuniyet ile memnuniyetin tahmin edilen olasılığ pozitif ilişkiye sahipken, memnuniyetsizliğin tahmin edilen olasılık değeri ile negatif bir ilişkiye sahiptirler (James, 2009: 107). Daha ayrıntılı açıklamak gerekirse, beklenti yanlışlaması yaklaşımına göre, beklenti ile yanlışlama arasında negatif bir ilişki mevcuttur. Yüksek beklentilerde daha çok yanılma söz konusu olup olumsuz yanlışlanırken, düşük beklentilere sahip olanlar daha az yanılma payı ile pozitif yanlışlanmaktadırlar. Yani yüksek beklentilere sahip bireylerin mal ya da hizmet performansı algıları ilk beklentilerini karşılayamamaktadır. $\mathrm{Bu}$ durumda negatif yanlışlama memnuniyetsizlik, pozitif yanlışlama ise memnuniyet göstergesi olarak değerlendirildiğinde; pozitif yanlışlama durumunda vatandaşların hizmetlerden algıladıkları performans geleceğe yönelik beklentilerden büyüktür ve negatif yanlışlama durumda ise beklentiler performanstan büyük olmaktadır.

1970’li yıllardan bu yana özel sektörde pratik uygulamalarına sıklıkla başvurulan beklenti yanlışlaması ve beklenti çıpası modellerinin bireysel veriler kullanılarak kamu sektörüne uyarlanmas1 ise görece daha yenidir (ör. James, 2009; Roch \& Poister, 2006; Van Ryzin, 2004). Bu alanda çalışma yapan ilk isimlerden Oliver James (2009: 118-120), İngiltere yerel yönetimlerinin çöp temizlik hizmetleri ile ilgili yaptığı araştırmada, bu hizmetleri kullanan vatandaşların memnuniyetleri ve aynı vatandaşların geleceğe yönelik beklentilerini kullanarak çöp temizlik hizmetlerine yönelik vatandaşların hizmet sunucunun performansını nasıl değerlendirdiğini ölçmüştür. İngiliz yerel yönetimlerde yönetimlerinde yaşayan vatandaşların hizmet sunucunun performansına bağlı olarak memnuniyetlerini şekillendirdiklerini, beklediği mal ve hizmeti alamayan vatandaşların yanlışlandığını ve yüksek beklentilere sahip vatandaşların memnuniyetlerinin düşük olduğunu saptamıştır.

James'in tespitleri, doğrudan kamusal mal ve hizmetlerin sunumundan vatandaş memnuniyetini temel alarak siyasi karar alma mekanizmasının mal ve hizmet sunum miktarının, kalitesinin vatandaş için ne derecede önemli olduğunu göstermesi ve bu performans algısının vatandaş beklentilerini de memnuniyetini de şekillendirdiğini ortaya koyması açısından önemlidir. Ayrıca kamusal mal ve hizmetlerden vatandaş memnuniyet verilerini kullanması ve 
yaşam memnuniyeti verilerini kullanmaması, kendisinin de belirttiği gibi, yaşam memnuniyeti literatürüne ilk kez kamu ve özel sektör arasında bu yolla bir kıyaslama yapma imkânı tanıması açısından da oldukça kayda değerdir.

James'in çalışması temel alınarak yaşam memnuniyeti alanında birçok çalışma yapılmıştır. $\mathrm{Bu}$ araştırmalar en geniş veri seti ile çalışanlardan biri de Forest V. Morgenson III'tür. Morgenson (2012: 295, 302-304) Amerika Müsşeri Memnuniyeti Endeksi'nin (ACSI) yerel, merkezi ve federal hükümet hizmetlerinden vatandaş memnuniyetlerini ölçen veri setini kullanarak yaptığı çalışmasında, vatandaşların memnuniyetlerinin, kamu hizmetinin sunum performansı ve beklentilerle yüksek derecede ilişkili olduğunu ve vatandaşların bekledikleri kamusal hizmet sunum performansını elde ettikleri sürece memnuniyetlerinin arttı̆̆ını tespit etmiştir.

Aslında hesap verilebilirliğin, objektif-sübjektif doğruluğun ve kamu hizmetlerinin kalitesinin arttırılması için 19601 y yllardan başlayarak giderek artan sayıda kamu kurumu vatandaş algılarına dayanan yöntemlerle proaktif öngörüler çerçevesinde vatandaşlardan aldıkları geri dönüşümlerle ölçümler yapmakta ve hareket etmektedir (OECD, 2013: 166). Hollanda'da "genel ölçüm aracı", İtalya'da "kalite barometresi" kamu hizmetleri tüketicilerinin memnuniyet düzeylerini ölçmek için kullanılan yöntemler iken İngiltere Kabine Ofisi(Cabinet Office, 2000) merkezi olarak 1990larda yapılan yerel bazda birey temelli, İngiltere Başbakan Yardımcısı Ofisi (Office of the Deputy Prime Minister, 2004) her bir yerel yönetim için ayrı ayrı yürütülmüş birey ve hane halkı temelli, Amerika Birleşik Devletleri Muhasebe Standartları Kurulu ise bazı eyaletlerde uygulaması yapılmış olan yaşam memnuniyet anketlerinden yararlanarak kamu hizmetlerinden memnuniyet ve memnuniyetsizlik durumlarını değerlendirmeye çalışmaktadır. Kamusal hizmetlerde memnuniyet, performans ve beklentiler açısından yapılan bu çalışmaların hizmet yönetimine getirdiği başarı sebebiyle, İngiltere'de yerel yönetim performanslarının değerlendirilmesi açısından İngiltere Başbakan Yardımcı Ofisi tarafindan Yerel Yönetimler Yasası (LGA) kapsamında her sene memnuniyet anketlerinin yapılması zorunlu tutulmuştur (LGA-1999; bölüm 3(1)).

Türkiye'de ise kamusal mal ve hizmetlerin sunumunda vatandaşların memnuniyet ve beklentilerini dikkate alarak hizmet sunma performansını ayarlayan bir kamu yönetim anlayışı henüz gelişmemiştir. Bu anlayışının geliştirilebilmesi için öncel olan bilimsel değerlendirmelerin yeşermesidir. Bu çalışmanın inceleme unsuru olan adalet hizmeti, bir tam kamusal mal olarak tüm toplumun ortak tüketimine koşulması, tüketiminde rekabet ve dışlama bulunmaması gibi etkiler sebebi ile ana akım literatürde genel değer yargılarını temsil eden bir görev yüklenmektedir. Dolayısı ile bu çalışmanın özgünlüğü sadece Türkiye'de adalet hizmetinin memnuniyetinden yola çıkarak kural yapıcıya yol gösterme nosyonundan değil aynı zamanda genel algıları yansitabilen daha önce bu tür analizlerde kullanılmamış bir mal grubu ve yöntem ile değerlendirmelerde bulunmasından da ileri gelmektedir.

\section{VERİ VE METODOLOJI}

Bu çalışmada Türkiye İstatistik Kurumu (TÜIK) 2012 yılı Yaşam Memnuniyeti Anketi soru ve sonuçları kullanılmıştır. Anket, hane halkı ve birey olmak üzere iki farklı mikro veri setinden oluşmakta olup, çalışmamızda yapılan analizler birey bazında yürütülmüştür. Bireylerin hayatlarından ve kamu hizmetlerinden memnuniyet düzeyleri, bu memnuniyet ya da memnuniyetsizlik durumlarının sosyo-demografik ve ekonomik unsur ile olan ilişkileri çalışmamız kapsamında açıklanmaya çalışılacaktır. Ayrıca beklenti yanlışlaması ve beklenti çıpası hipotezlerinin Türkiye örneğinde test edilmesi amacıyla adalet hizmetlerinin sunumuna yönelik beklenti ile memnuniyet değişkenini temsilen performans eksi beklenti değişkeni analizlere dâhil edilecektir. Araştırma yöntemi olarak kümülatif normal dağılım esasına dayanan 
belirli bir bağımlı değişken rasyosuna ulaşmak için gerekli bağımsız değişken etkisinin tahmin edilmesine yarayan ikili probit regresyon modeli seçilmiştir.

2012 Yaşam Memnuniyeti Anketi’nde "bir bütün olarak düşündüğünüzde hayatınızdan ne kadar mutlusunuz?" ve bu çalışmada analizi yapılan adalet ve asayiş hizmetleri için "hizmetlerden ne kadar memnunsunuz?" soruları ile bireylerin memnuniyet düzeyleri saptanmıştır. Cevaplar her bir soru için ayrı ayrı olmak üzere 1 ila 5 arasında derecelendirilmiştir.

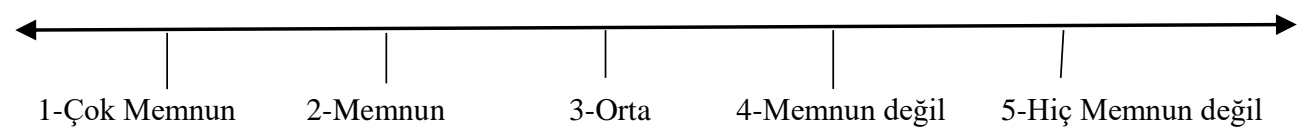

Adalet hizmetinden memnuniyet ve memnuniyetsizlik ile asayiş hizmetlerinden memnuniyet ve memnuniyetsizlik durumları için ayrı modeller kurulmuş, kamu hizmetlerinden memnun olma ve memnun olmama durumları her bir modele değişmek kaydı ile bağımlı değişken olarak kullanılmıştır. İkili (binary) probit yönteminin gereği olarak 5'li Likert ölçeği yukarıda gösterildiği üzere derecelendirilen memnuniyet hali 0 ve 1 düzeyine indirgenmiştir. Bu işlem, uç noktaların kendi bağlı bulundukları grup içerisinde değerlendirilmesi ile yapılmıştır. Yani, 1 "çok memnun" ve 2 "memnun" seçenekleri 1 "memnun" altında; 4 "memnun değil" ve 5 "hiç memnun değil" ölçekleri ise 0 "memnun değil" başlığı altında birleştirilmiş̧tir.

Her ne kadar memnuniyet ölçeklerinin "çok" ve/veya "hiç" gibi uç dereceleri kamu hizmeti sunan sorumlu yerel yönetime oy vermek ya da vermemek noktasında önemli olduğu varsayımı ile bazı çalışmalarda kullanılmış (Lyons \& Lowery, 1992: 19-45) olsa da çalışmamızda kamu hizmetlerinden memnuniyet derecelerinin kendi içlerindeki anlamlılık düzeyleri ve değişimleri göz ardı edildiği için bu uç noktalar analize dâhil edilmemiştir. Benzer şekilde Oliver James (2009: 112-114)'in çalışmasında uç değerleri analiz dışına itmiş; daha öz, daha esasa ilişkin önem arz eden memnuniyet ve memnuniyetsizlik ölçekleri ile çalışmıştır.

Ayrıca Anket'te “Gelecekten ne kadar umutlusunuz?" sorusu ile vatandaşın geleceğe yönelik genel beklenti algısını saptamaya çalışırken "Ülkemizin kamu hizmetlerinin sunumu açısından gelecekte nasıl değişeceğini düşünüyorsunuz?" sorusu beklenti çıpası ve beklenti yanlışlama hipotezlerini test etmek için kullanacağımız beklenti verilerini ortaya çıkarmaktadır. Genel umut düzeyi 1 ile 4 arasında 1 "çok umutlu", 4 "hiç umutlu değil" olmak üzere derecelendirilirken kamu hizmetlerinin sunumu açısından beklentiler 1 "iyi yönde değişecek", 2 "aynı kalacak", 3 "kötü yönde değişecek" ve 4 "fikrim yok" olmak üzere ölçeklendirilmiştir. Yani bu sorularda 4lü Likert ölçeği kullanılmıştır. "Fikrim yok" seçeneği çalışmaya ek bir katkı yapmayacağı düşünülerek kapsam dışına itilmiştir.

Anket kullanıcılarına yaş, cinsiyet, yerleşim yeri, eğitim durumu gibi sosyo-demografik ve gelir seviyesi, iş durumu gibi sosyo-ekonomik soruların yanı sıra kamu hizmetlerin sunumu açısından vatandaş beklentilerini ortaya çıkarmaya yönelik sorular da sorulmuştur. Analizlerde bu unsurların kullanılmasının sebebi vatandaş isteklerinin hangi öğeler çerçevesinde şekillendiği anlayabilmek ve vatandaş profillerine uygun hizmet sunulmasını sağlayabilmektir. Hane halkı büyüklüğü örnek veri setinde 1'den 16'ya kadar hanehalkı büyüklükleri olarak verilmişken, Türkiye için çekirdek ailenin dört kişiden oluştuğu varsayımı ile dörtlü kümelere ayrılarak üç ayrı grup içerisinde kategorik olarak değerlendirilmiştir.

Bireye yöneltilen son bir haftadır bir işte çalışıp çalışmadığına dair sorunun cevap şıkları; 1 "çalışıyor", 2 "çalışmıyor ama işle ilgisi devam ediyor" ve 3 "çalışmıyor" yeniden düzenlenerek birinci ve ikinci seçenek birleştirilmiş böylece çalışan ve işsiz olmak üzere ikili bir ayrım yaratılmıştır. Aslında bu indirgeme işsiz bir birey ile çalışan bir bireyin memnuniyet tercihleri ve beklentileri arasındaki bağıntı ya da farklılığın bulunmasına da diğer değişkenler 
sabitken doğrudan yardımcı olacaktır. Medeni hal durumu veri ise evli, bekâr, eşi ölmüş, eşinden ayrı yaşıyor gibi seçenekler ikili forma kavuşturularak evli ve bekâr olarak nitelendirilmiştir.

Regresyon çeşitlerinden lojistik ve probit regresyon yaklaşımları bağımlı değişken ya da tam ifadesi ile yanıt değişkeni kesikli veri halinde ise uygulanabilecek yöntemlerden olup çalışmamız dâhilinde kullanılan ikili probit regresyonu yanıt değişkeni iki düzeye indirgendiğinden (memnun/memnun değil) ötürü tercih edilmiştir. Kümülâtif standart normal dağıllışın tersi (Topcu, 2008, s.208) olarak da tanımlanabilecek probit regresyonumuzda açılayıcı değişken sayımız her bir modelde hepsi kullanılmamak koşulu ile on iki tanedir.

Tahmin edilen regresyon modelimizin fonksiyonel formlu kavramsal denklemi şöyledir:

Tablo 1: Modellerde Kullanılan Değişkenlerin Açıklamaları

\begin{tabular}{|c|c|}
\hline Model 1 için & Model 2 için \\
\hline $\begin{array}{l}\text { KHM } \rightarrow \text { f( YAŞ, YER, CIN, MH, ED, İS, HAM, HHB, } \\
\text { MEB) }\end{array}$ & $\begin{array}{l}\text { KHM } \rightarrow \mathrm{f}(\text { YAŞ, YER, CİN, MH, ED, İS, HAM, HHB, } \\
\text { B) }\end{array}$ \\
\hline KHM= Kamu Hizmetlerinden Memnuniyet & KHM= Kamu Hizmetlerinden Memnuniyet \\
\hline $\begin{array}{l}\text { YAŞ= Kamu Hizmeti Kullanıcı olan Vatandaşların } \\
\text { Yaşları }\end{array}$ & $\begin{array}{l}\text { YAŞ= Kamu Hizmeti Kullanıcı olan Vatandaşların } \\
\text { Yaşları }\end{array}$ \\
\hline $\begin{array}{l}\text { YER = Kamu Hizmet Kullanıcılarının Yerleşim Yerleri } \\
\text { (Kent- Kır) }\end{array}$ & $\begin{array}{l}\text { YER = Kamu Hizmet Kullanıcılarının Yerleşim Yerleri } \\
\text { (Kent- Kır) }\end{array}$ \\
\hline $\mathrm{K}=\mathrm{Kent}$ & $\mathrm{K}=\mathrm{Kent}$ \\
\hline $\begin{array}{l}\text { CiN= Kamu Hizmeti Kullanıcılarının Cinsiyetleri } \\
\text { (Erkek-Kadın) }\end{array}$ & $\begin{array}{l}\text { CiN= Kamu Hizmeti Kullanıcılarının Cinsiyetleri } \\
(\text { Erkek-Kadın) }\end{array}$ \\
\hline $\mathrm{E}=$ Erkek & $\mathrm{E}=$ Erkek \\
\hline $\begin{array}{l}\text { MH= Kamu Hizmeti Kullanıcılarının Medeni Hal } \\
\text { Durumu (Evli -Bekar) }\end{array}$ & $\begin{array}{l}\mathrm{MH}=\text { Kamu Hizmeti Kullanıcılarının Medeni Hal } \\
\text { Durumu (Evli -Bekar) }\end{array}$ \\
\hline $\begin{array}{l}\text { ED= Kamu Hizmeti Kullanıcıların Eğitim Durumu (yedi } \\
\text { düzeyde) }\end{array}$ & $\begin{array}{l}\text { ED= Kamu Hizmeti Kullanıcıların Eğitim Durumu (yedi } \\
\text { düzeyde) }\end{array}$ \\
\hline $\begin{array}{l}\text { İS= Kamu Hizmeti Kullanıcılarının İş Durumu (İşi var- } \\
\text { İşsiz) }\end{array}$ & $\begin{array}{l}\text { İS= Kamu Hizmeti Kullanıcılarının İş Durumu (İşi var- } \\
\text { İşsiz) }\end{array}$ \\
\hline $\begin{array}{l}\text { İss }=\text { Anket yapıldığı tarih itibari ile bir işte } \\
\text { çalışmayan kamu hizmet kullanıcıları }\end{array}$ & $\begin{array}{l}\text { İss }=\text { Anket yapıldığı tarih itibari ile bir işte } \\
\text { çalışmayan kamu hizmet kullanıcıları }\end{array}$ \\
\hline $\begin{array}{l}\text { HAM = Kamu Hizmeti Kullananların Genel olarak } \\
\text { Hayattan Memnuniyet Durumları }\end{array}$ & $\begin{array}{l}\text { HAM = Kamu Hizmeti Kullananların Genel olarak } \\
\text { Hayattan Memnuniyet Durumları }\end{array}$ \\
\hline $\begin{array}{l}\text { HHB = Kamu Hizmeti Kullananların Hane halklarının } \\
\text { Büyüklüğü }\end{array}$ & $\begin{array}{l}\text { HHB = Kamu Hizmeti Kullananların Hane halklarının } \\
\text { Büyüklüğü }\end{array}$ \\
\hline $\begin{array}{l}\text { MEB = Kamu Hizmetlerinden Memnuniyet eksi Kamu } \\
\text { Hizmetleri Sunumundan Beklenti }\end{array}$ & B = Kamu Hizmetleri Sunumundan Beklenti \\
\hline
\end{tabular}




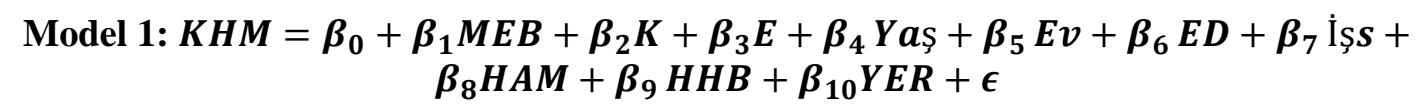

$$
\begin{aligned}
& \text { Model 2: } K H M=\beta_{0}+\beta_{1} B+\beta_{2} K+\beta_{3} E+\beta_{4} Y a s ̧+\beta_{5} E v+\beta_{6} E D+\beta_{7} \text { İșs + } \\
& \beta_{8} H A M+\beta_{9} H H B+\beta_{10} Y E R+\epsilon
\end{aligned}
$$

$\mathrm{P}$ değerleri ile Wald Ki-Kare değerleri, kurulan modelin uyumunu ve istatistiksel anlamlılı̆̆ ifade etmek amacıyla her bir tabloda ayrı ayrı gösterilmektedir. Analizlerin tamamı robust tekniği uygulanarak yürütülmüştür. Ayrıca analizlerde kullanılan bağımlı değişkeler kategorik yapıda olduğundan en küçük kareler yöntemi yerine maksimum olabilirlik yöntemi benimsenmiştir.

Belirtilen modeller, tercih belirleme ve açıklatma mekanizmalarından, doğrudan tahmin yöntemleri içerisinde yer alan yaşam memnuniyeti yöntemi kullanılarak oluşturulmuş ve değerlendirilmiştir. Açıklanmış ve belirlenmiş tercihler teorilerinin kesişim noktasında bulunan bu yöntemde, bireylerin tercih ve taleplerinin içinde bulundukları gruba ve grup içerisindeki sosyal etkileşimlerine bağlı olarak değiştiği kabul edilmektedir. Fakat her bireyin tercihlerinin, tecrübe ve memnuniyetlerinin farklı olması dolayısı ile eşsiz olduğu fikrine dayanan tercih faydacılı̆g 1 (preference utilitarianism) kavramı temel alınmaktadır (Ng, 2000: 5). Yöntemin kullandığ 1 anketlerde mal memnuniyet ve beklenti dışında mal/hizmetin bedeline yönelik herhangi bir soru bulunmadığı için, yöntem bireylerin tercihlerini herhangi bir yargı ve/veya etki altında kalmaksızın dürüst biçimde açıklamalarını sağlamaktadır. Dolayısıyla bireylerin verdikleri cevaplar, mal ve hizmet düzeyleri ile ilişkilendirildiğinde o hizmeti sunan kurumlara verdikleri hizmetlerin etkin ve etkili bir biçimde kullanılıp kullanılmadığı daha önce kurum tarafından belirlenen hedeflere ulaşılıp ulaşılmadığı açısından doğru bilgiler sunmaktadır. Yaşam memnuniyeti yönteminde bireylerin beklentileri ve memnuniyetleri arasındaki ilişkiler ile kamusal malın sunum performansına yönelik düşünceleri ise beklenti çıpası, beklenti yanlışlaması hipotezlerinin sınanması yolu ile gerçekleştirilmektedir (ör. James, 2009; Roch \& Poister, 2006; Van Ryzin, 2004).

Beklenti yanlışlaması hipotezinde beklenti ile yanlışlama arasında negatif bir ilişki vardır; yüksek beklentilerde daha çok yanılma dolayısıyla negatif yanlışlama, düşük beklentilerde ise daha az yanılma payı nedeniyle pozitif yanlışlama söz konusudur. Beklentiler ile yanlışlama arasında negatif ilişki, performans ile de memnuniyet arasında pozitif bir ilişki olduğu kabul edildiğinde memnuniyet ile beklentiler arasındaki fark pozitif olduğu müddetçe pozitif yanlışlama, fark negatif olduğunda ise negatif yanlışlamadan bahsetmek yanlış olmayacaktır.

Beklenti çıpası hipotezi; yüksek hizmet sunumu beklentilerinin sunulan hizmetlerden memnuniyet ile negatif ilişkili olduğu varsayımında bulunur. Çalışmamızda memnuniyet, memnuniyetsizlik ve beklentilere dair uç noktalar kendi grupları içerisinde yer alan diğer değerler ile birleştirildiğinden ( 1 çok memnun ve 2 memnun birleştirilmiş ve 1 memnun olarak yeniden düzenlenmişti) aynı hipotezi beklentiler ile memnuniyet arasındaki negatif ilişkinin varlığı yoluyla test edilmiştir. 


\section{BULGULAR VE DEĞERLENDİRME}

Çalışmamızda iki temel hipoteze Türkiye örnekleminde cevap aranmaktadır:

$H_{1}$ : Memnuniyet eksi beklentiler memnuniyetle pozitif ilişkilidir

$\mathrm{H}_{2}$ : Beklentiler ile memnuniyet arasında negatif ilişkili vardır

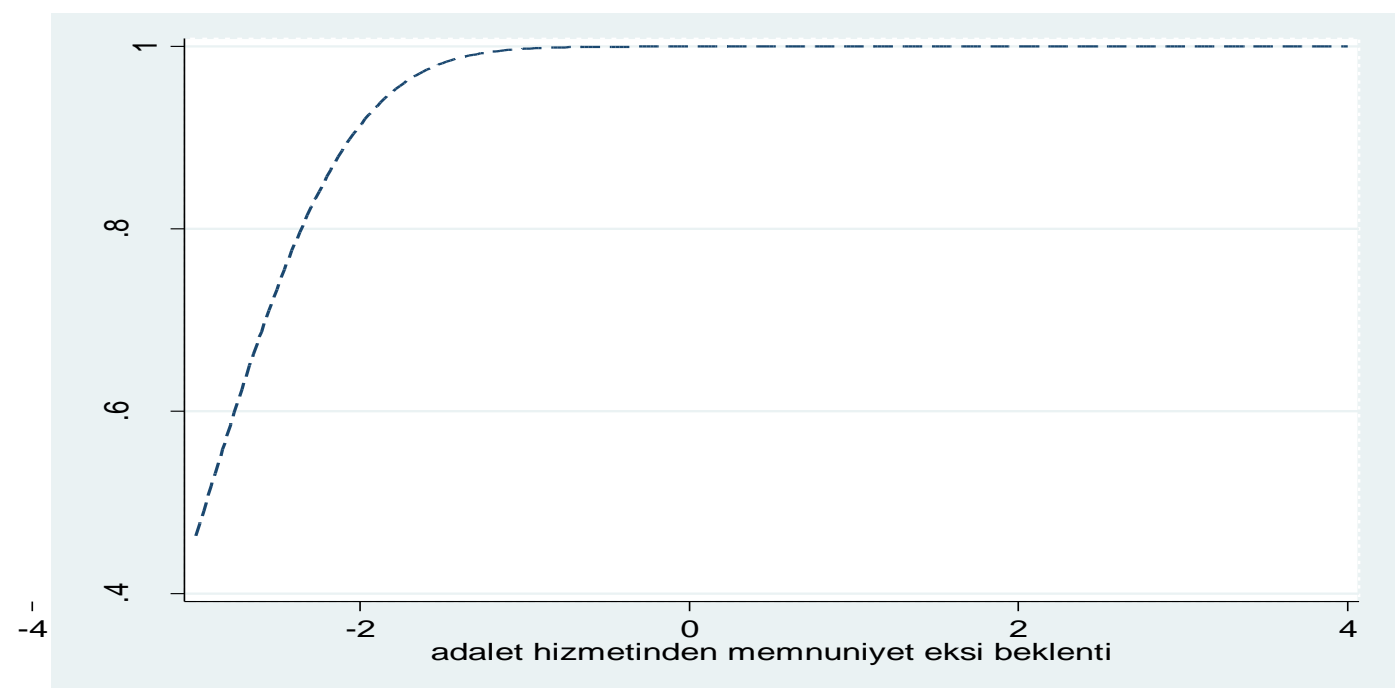

Grafik 1: Adalet Hizmetlerinden Memnuniyetin Olasıllı̆

Kaynak: Yazarlar tarafindan oluştrulmuştur.

Grafik 1'de adalet hizmetinden duyulan memnuniyete yönelik tahmin edilen olasılık değerleri, bu hizmetlerden memnuniyetin grafiklerle uyumlu katsayı değerleri ise Tablo 2'de yer almaktadır. Grafik 1'den görüleceği üzere, adalet hizmetlerinden memnuniyet söz konusu olduğunda memnuniyet ile memnuniyet eksi beklenti arasındaki ilişki pozitiftir. Bir başka deyişle hizmetlerden duyulan memnuniyet, aynı hizmetlere yönelik beklentilerden büyük olduğu sürece olasılık artmaktadır.

Tablo 2 ikili probit regresyon analizinin adalet hizmeti için bulgularını göstermektedir ve memnuniyet bağımlı / yanıt değişken olarak kullanılmıştır. Memnuniyet düzeylerinin memnuniyet eksi beklenti ve diğer değişkenlerle olan ilişkilerini ifade etmek adına model 1, memnuniyet düzeylerinin bu hizmetlerden beklentilerle olan ilişkilerini göstermek adına da model 2 oluşturulmuştur. 
Tablo 2: Adalet Hizmetinden Memnuniyetin İkili Probit Regresyon Analizi

\begin{tabular}{|c|c|c|}
\hline \multirow[t]{2}{*}{ Değişkenler } & \multicolumn{2}{|r|}{ Modeller } \\
\hline & Model 1 & Model 2 \\
\hline Memnuniyet eksi Beklenti & $1.451111 * * *(0.0716011)$ & \\
\hline Beklenti & & $0.1745628 * * *(0.02176)$ \\
\hline Düşük Beklenti & & $0,273 * * *(0,06)$ \\
\hline Yüksek Beklenti & & Referans kategori \\
\hline Kent & $-0.1649284 *(0.0888113)$ & $-0.2880278^{* * *}(0.0662018)$ \\
\hline Erkek & $0.1808229 * * *(0.0694078)$ & $-0.0493236(0.0528357)$ \\
\hline Yaş & $-0.0085216^{* * *}(0.0026049)$ & $-0.0033103 *(0.0019136)$ \\
\hline Evli & $-0.048989(0.0743329)$ & $-0.0845216(0.0556017)$ \\
\hline Eğitim Durumu & $-0.1167896^{* * *}(0.0230234)$ & $-0.2222458 * * *(0.0162289)$ \\
\hline İşsiz & $0.0020218(0.071093)$ & $0.0535201(0.0541942)$ \\
\hline Hayat memnuniyeti & $0.45512 * * *(0.041237)$ & $0.3320872 * * *(0.0292324)$ \\
\hline HaneHalkı Büyüklüğü & $0.004051(0.0240262)$ & $-0.012715(0.0142957)$ \\
\hline Wald $\mathrm{Chi}^{2}(11)$ & 471.15 & 380.48 \\
\hline $\mathbf{N}$ & 4276 & 4276 \\
\hline Sabit & $3.997277 * * *(0.2332202)$ & $3.150405^{* * *}(0.1601341)$ \\
\hline \multicolumn{3}{|c|}{ 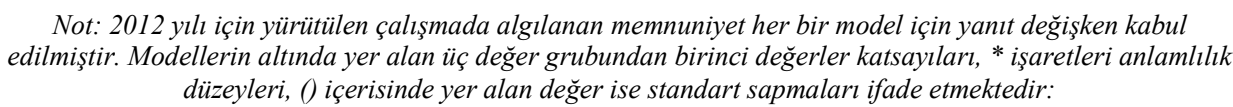 } \\
\hline & ${ }^{*} p<0,1, * * p<0.05 v e^{* * *} p$ & \\
\hline
\end{tabular}

Kaynak: Yazarlar tarafindan oluştrulmuştur.

Kırda yaşayan vatandaşların kentte yaşayan vatandaşlara göre adalet hizmetlerinden daha memnun oldukları tespit edilmiştir. Vatandaş memnuniyeti ile kentte yaşayan vatandaşlar arasındaki bu ilişki \%90 düzeyinde anlamlıdır. Ayrıca kentte yaşayan bireylerin bahsi geçen kamusal hizmetlerin sunumuna yönelik olarak inşa ettikleri beklentilerinin de kırda yaşayanlara göre daha karamsar eğilimde olduğu tespit edilmiştir.

Ek olarak erkeklerin kadınlara göre hizmetlerden daha memnun olduğu, beklentilerinin ise memnuniyetle ters oranlı olduğu saptanmıştır. Yaşa bağlı olarak adalet hizmetlerinin sunumuna yönelik memnuniyetin azaldığı tespit edilmiştir ve bu ilişki \%99,9 düzeyinde, son derece, anlamlıdır. Bireylerin medeni hal durumu ise önemli bir memnuniyet göstergesi değildir. Ancak evli bireylerin bekâr bireylere kıyasla memnuniyet düzeyleri daha düşüktür.

Tablo 2'de de görüleceği üzere, çalışma kapsamında yürütülen analizler eğitim düzeyi arttıkça ilgili kamusal hizmetin sunumundan memnuniyetin azaldığını ve eğitim düzeyi ile memnuniyet arasında oldukça güçlü bir ilişki olduğunu ortaya koymaktadır. Benzer şekilde eğitim düzeyi arttıkça beklentilerle memnuniyet arasında daha güçlü bir negatif ilişki ortaya çıkmaktadır ki eğitim hizmetleri için beklenti çıpası hipotezinin çok güçlü bir biçimde doğrulandığı görülmektedir. Bir işyerinde anket yapıldığı sırada çalışmayan ya da işsiz olan bireylerin adalet hizmetlerinden memnuniyeti ise anlamlı olmamakla birlikte beklentilerine göre daha yüksektir yani pozitif olarak yanlışlanmaktadır. Beklentilerin memnuniyet ile ilişkisi ise işsiz vatandaşlar için negatif değil pozitif ilişkilidir. Yani, işsiz hizmet kullanıcıları hizmetlerden memnuniyet konusunda neredeyse kayıtsızdır. 
Türkiye'de genel olarak kamu hizmetlerinden memnuniyet, beklenti ve performans değerlendirildiğinde, hayatlarından genel olarak memnun olan vatandaşların kamu hizmetlerinin sunumundan da son derece memnun oldukları gözlemlenmektedir. Ayrıca, yapılan incelemelerde kent, kır, evli, bekâr, eğitim seviyesi gibi unsurlarda görülmeyen bir yönde kamu hizmetlerinden memnuniyetleri ile ileride bu kamu hizmetlerinin sunumuna yönelik beklentileri pozitif şekillenmektedir. Yani, memnuniyetleri arttıkça beklentileri artmakta ya da tam tersi ama mutlaka anlamlı bir düzeyde söz konusu olmaktadır.

Çalışmamızda kadınların adalet memnuniyetlerinin erkeklere nazaran daha düşük olduğu gözlemlenmiştir. Bu bilgi bu alanda farklı mal ve hizmet grupları ile yapılan çalışmalarla uyumludur. Gerek özel hizmetlerinde (Juwaheer, 2011; Lin vd, 2001; Snipes vd., 2006; Tan \& Kek, 2004) gerekse belediyeler tarafindan sunulan yerel nitelikteki kamusal hizmetlerde (Akinboade vd., 2014; Mansor \& Razali, 2010; Mokhlis vd., 2011; Senik, 2004) kadınların erkeklere nazaran hizmet memnuniyetinin daha düşük olduğu gözlemlenmiştir. Benzer şekilde yarı kamusal mal ve hizmet kabul edilen eğitim ve sağlık mallarına yönelik birey memnuniyetini analiz eden Ahlereup vd. (2016) ve bu çalışmada olduğu gibi beklenti çıpası ve beklenti yanlışlaması hipotezlerini işin içerisine sokarak çöp ve temizlik işleri için aynı analizi yürüten James (2009)'de kadınların erkeklere göre mal memnuniyetlerinin daha düşük olduğunu tespit etmişlerdir. Ancak yarı kamusal mal ve hizmetlerden vatandaş memnuniyeti (CastellanosCerreceda, 2013; Gandelman \& Hernandez-Murillo, 2012; Kotarkopi \& Laamanen, 2007) ve kamusal iyi ve kötülerden memnuniyetini (Ferreira vd., 2006; Van Ryzin, 2004) ele alan diğer çalışmaların aksi yönde sonuç elde ettiği de belirtilmelidir. Fakat önemli bir not olarak yukarıda sıralanan çalışmaların tümünde, çalışmamızda olduğu gibi cinsiyetin mal ve hizmetlere yönelik tercih ve talepleri etkileyecek önemli bir faktör olduğu tespit edilmiştir.

Bu çalışmadan önce Frey vd. (2009) ve Brenig \& Proeger (2016) dışında bu çalışmada seçilen yaşam memnuniyeti yöntemiyle ikili probit regresyon analizi kullanarak tam kamusal mal ve hizmetlere yönelik birey memnuniyeti analiz edilmemiştir. Belirtilen çalışmalar ise bu çalışmanın konusunu oluşturan adalet hizmeti değil asayiş hizmetleri üzerinedir. Bu çalışmayı özellikli kılan bu husus bir kenara bırakıldığında; Frey vd. (2009) ile Brenig \& Proeger (2016)'in çalışmalarında kadınların memnuniyet düzeylerinin erkeklere nazaran daha yüksek olduğu sonucuna ulaşıldığ 1 da ayrıca eklenmelidir.

Tüm bunların yanı sıra, çalışmamızda Türkiye'de hizmet kullanıcıların yaşadığı yerin kent ve/veya kırsal olmasının da adalet hizmetinin sunumundan vatandaş memnuniyeti üzerinde son derece anlamlı olduğu; kentte yerleşik vatandaşların kırsalda yaşayan hizmet kullanıcılara göre hizmetlerden memnuniyet eğilimlerinin daha düşük olduğu bulunmuştur. $\mathrm{Bu}$ sonuç bireylerin hizmet memnuniyeti ile yerleşim yeri arasındaki ilişkiyi ortaya koyan alan çalışmalarıyla da örtüşmektedir (Brening \& Proeger, 2016; Castellanos-Cerreceda, 2013; Duffy, 2000; Gandelman \& Hernandez-Murillo, 2012; Li, 2008; Michelson \& Read, 2011; Senik, 2004; Van Ryzin 2004).

Araştırma kapsamında ele alınan bir diğer sosyo-demografik unsur ise yaştır. Adalet hizmetlerinden memnuniyet için yaş kriteri önemli bir öğedir. Tercih ve talepleri etkileyici bir öğe olarak yaşın etkisi Senik (2004) harici tüm bahsi geçen alan çalışmalarınca onaylanmaktadır. Ayrıca Türkiye'de eğitim seviyesi ile memnuniyetin son derece anlamlı ve negatif ilişkiye sahip olduğu gözlemlenmiştir. Ek olarak çalışmamızda evli bireylerin bekârlara nazaran adalet hizmetinin sunumundan daha az memnun oldukları tespit edilmiştir. Yaşam memnuniyeti kullanılarak yapılan çalışmalarda bireylerin yaşam memnuniyeti ile evli olma durumu arasındaki pozitif ilişkiye değinilirken (Ahlerup vd., 2016; Brening \& Proeger, 2016; Frey vd., 2009; Gandelman \& Hernandez-Murillo, 2012; Kotakorpi \& Laamanen, 2007; Levinson, 2009; Salinaz-Jimenez vd., 2011) bizim ulaştığımız sonuçların bu yönde olması tesadüfi değildir. Çünkü evli bireyler bekâr bireylere nazaran adalet sistemini daha çok kullanmakta ve bu mala 
doğrudan maruz kalmaktadır. Zaten Türkiye'deki kullanıcı profili incelendiğinde kentte yaşayan bireylerin kırsalda yaşayan bireylerden evli bireylerin bekâr bireylerden, eğitimli bireylerin eğitimsiz bireylerden daha çok mahkemeye başvurdukları gözlemlenmektedir. Enteresan bulgu ise işsiz bireylerin adalet hizmetlerinden memnuniyetinin hâlihazırda istihdam edilen bireylere kıyasla daha yüksek olmasıdır.

Bireylerin kamusal mal memnuniyetini etkilemesi açısından sosyo-demografik öğeleri ile alan Türk literatüründeki çalışmalar da incelenmiştir. Muş vd. (2014) ve Caner (2016) kadınların mal memnuniyetinin erkeklere nazaran daha yüksek olduğunu, Bölükbaşı ve Yıldırtan (2010) ile Daştan ve Delice (2015) ise erkeklerin kamusal mal ve hizmet memnuniyetlerinin kadınlara nazaran daha yüksek olduğunu savunmaktadır. Kırsalda yaşayan bireylerin kamusal mal memnuniyetinin kentlerde yaşayan bireylere göre daha yüksek olduğu savı Eren (2015) ve Muş vd. (2014) tarafından desteklenirken, Gürsakal ve Öngen (2010)'in çalışmasındaki bulgular tarafindan desteklenmemektedir. Muş vd. (2014), Daştan ve Delice (2015) ile Caner (2016) çalışmalarında medeni hal durumunun memnuniyet etksini bu çalışma ile benzer tespit etmişlerdir. Eğitim düzeyi ile kamusal mal memnuniyeti arasındaki ilişki irdelendiğinde ise Bölükbaş1 ve Yıldırtan (2010), Başaran vd. (2014) ve Muş vd. (2014)'nin eğitimsiz bireylerin eğitimli bireylere göre kamusal malın sunumuna yönelik memnuniyetlerinin daha yüksek olduğunu saptadıkları anlaşılmıştır. Bu sonuçlar bu çalışmadaki savı da desteklemektedir.

Fakat bu çalışmanın temel konusu tercih ve talepleri etkileyen sosyo-demografik unsurlarla birlikte değerlendirildiğinde bireylerin geleceğe yönelik beklentilerinin hükümetlerin mal/hizmet sunum performanslarına yönelik vatandaş algısını nasıl değiştirdiği olduğu için beklenti çıpası ve beklenti yanlışlaması hipotezlerine ayrı önem göstermek gerekmektedir. Bu çalışma kapsamında elde edilen bulgularla literatürde bu hipotezleri çalışan araştırmacıların (James, 2009; Oliver, 1980; Van Raaij, 1989) sonuçlarının uyumlu olduğu ve Türkiye örneğinde adalet malı için her iki hipotezinde onaylandığı söylenebilmektedir. Memnun edilebilirliğin tahmin edilen olasılığ kamu hizmetlerinin sunumuna yönelik vatandaş beklentilerinin ötesine geçmekte ve hizmetlerden algilanan memnuniyet ile beklenti arasındaki fark memnuniyetle beraber pozitif ilişkili artmaktadır.

\section{SONUÇ VE ÖNERILER}

Tam kamusal mallar toplumun tamamı için üretilerek sunulan, kimsenin tüketimden dışlanamadığ 1 ve tüketiminde rekabet edilmeyecek mal ve hizmetler olduğu için bu mal/hizmete yönelik bireysel tercihler birbirlerinden çok uzak bir noktada oluşmamaktadır ve bu sebeple genel toplumsal kanıyı yansitma hususunda daha az saptırıcıdır. Ancak yine de piyasa başarısızlıklarının oluşmasının temelinde yatan bireylerin tercihlerin açıklamama problemi burada kendini göstermektedir. Bireylerin tercih ve talepleri ile ilgili doğru bilgiler edinilmediğinde ise kaynakların etkin tahsis edilmemesi, optimal sunum düzeyinin altında kalınması ve kamu zararı minvalinde problemler ortaya çıkmaktadır. Koşullu değerleme yöntemi gibi bir doğrudan tahmin yöntemi olarak aynı zamanda tercih açıklatma mekanizmalarından biri olan yaşam memnuniyeti yöntemi ise bu soruna çözüm bulduğu iddiasında olan yaklaşımlardandır. Bünyesinde kamusal mal ve hizmet bedelinin ödettirilmesi ile ilgili herhangi bir soru barındırmadığından ya da böyle bir algı yaratmadığından bireylerin istek ve tercihlerini herhangi bir yargı ve/veya etki altında kalmaksızın dürüst biçimde açıklamalarını sağlamaktadır. Ayrıca bireylerin verdikleri cevaplar, mal ve hizmet düzeyleri ile ilişkilendirildiğinde o hizmeti sunan kurumlara verdikleri hizmetlerin etkin ve etkili bir biçimde kullanılıp kullanılmadığının veya daha önce kurum tarafından belirlenen hedeflere ulaş1lıp ulaşılmadığının tespiti daha doğru yapılabilecektir. Bu sebeplerden ötürü bireylerin demografik ve ekonomik özellikleri temelinde profillerinin belirlenmesi hizmet sunumunun ve kalitesinin iyileştirilmesi açısından elzemdir. 
Genel bir değerlendirme yapılması gerekirse araştırmamız sonuçlarına göre, adalet hizmetlerinde politika yapıcı ve bu hizmetlerin sunucusu olan devlet kurumları tüm vatandaşlara yönelik genel politikaların yanı sıra kamu hizmetlerinden görece daha memnuniyetsiz olan gruplara farklılaştıılmış hizmette sunmalı ya da sunulan hizmetlerin kalitesi ve sunumunda bu sayılan grupların talepleri doğrultusunda iyileştirmeye gidilmesi gerektiği söylenebilir. Çünkü bu çalışma kapsamında talebi etkileyen unsurlar incelendiğinde, evli bir kadın olup da kentte yaşayan eğitimli bireylerin, adalet sistemini ve ürettiği adalet malını kamu tarafından sunulduğu şekliyle kullanmak istemediği görülmektedir. $\mathrm{Bu}$ durum özellikle son yirmi yıldır adalet sisteminin yarattığı boşluklar sebebi ile istismara ve şiddete uğrayan kadınların toplumdaki genel kanılarıyla oldukça uyumludur.

İleride yapılacak diğer çalışmalara yön vermek, yol göstermek açısından araştırmamızın kısıtlarından da bahsetmeliyiz. Çalışmamız yaş, cinsiyet, yerleşim yeri, işsizlik gib sübjektif verilerle yürütülmüştür. Bu alanda yapılan diğer çalışmalarda olduğu üzere (James, 2009; Stipak, 1980; Van Ryzin, 2006) objektif performans ve memnuniyet arasındaki pozitif ilişki ya da objektif beklenti ile memnuniyet arasındaki negatif ilişki açısından bir önerme oluşturmamakta; objektif verilerle yapılacak daha başka çalışmaların konusunu teşkil etmektedir.

\section{KAYNAKÇA}

Abdullah, H.S. \& Kalianan M. (2008). From customer satisfaction to citizen satisfaction: rethinking local government service delivery in malaysia. Asian Social Science, 4(1), 87-92.

Ahlerup P., Baskaran T. \& Bigsten A. (2016). Public goods and tax compliance: the case of local health care in Rwanda. (International Growth Centre (IGC) and African Tax Administration Forum Joint Publication Working Paper). University of Gothenburg Centre of Globalization and Development.

Akçakaya, M. (2012). Kamu sektöründe performans yönetimi ve uygulamada karşılaşılan sorunları. Karadeniz Araştırmaları, Sayı 32, 171-202.

Akgül, A. (2003). Kamu yönetim siteminin dna'sını değiştirme modeli: değişim mühendisliği. Türkiye İsrafı Önleme Vakfı Yayınları Türkiye'nin Sorunlarına Çözüm Serisi, 1.

Akinboade, O.A., Mokwena M.P \& Kinfack E.C. (2014). Protesting for 1mproved public service devlivery in south africa's sedibeng district. Social Indicators Research. 119 (1): 1-23.

Arizti, P., Brumby J., Manning N., Senderowitsch R. \& Thomas T. (2010). Results, performance budgeting and trust in government. The World Bank, 1-269.

Başaran, M.A., Başaran, A.A., Çetinkaya, M. \& Erkam S. (2014). Kamu hizmetlerinde performans denetimi ve memnuniyet: asayiş hizmetlerinde memnuniyetin bulanık mantık temelli analizi. 29. Türkiye Maliye Sempozyumu Bildiri Kitabı içinde (ss. 105-123), Sakarya.

Baujard, A. (2013). Utilitarianism and anti-utilitarianism. Handbook of the history of economic analysis. (Vol. 3, Developments in major fields of economics). Cheltenham (UK): Edward Elgar Publishing Limited.

Bentham, J. (1795). A Manual of political economy. London: Allen and Unwin.

Bentham, J. (1954). Jeremy Bentham's economic writings. (W. Stark, Der.). Vol 3. London: Allen and Unwin.

Bentham, J. (2000). An introduction to the principles of morals and legislation. Original book published in 1789. Kitchener: Batoche Book.

Blaug, R., L. Horner \& Lekhi R. (2006). Public value, citizen expectations and user commitment, a literature review. London: Work Foundation.

Bölükbaşı A.G. \& Yıldırtan D. Ç. (2010). Yerel yönetimlerde belediyenin başarısını ve yaşam memnuniyetini etkileyen faktörler üzerine bir alan araştırması. Marmara Üniversitesi Sosyal Bilimler Hakemli Dergisi, 9 (33), 237235.

Brenig, M. \& Proeger T. (2016). Putting a price tag on security: subjective well-being and willingness to pay for crime reduction in Europe. (Discussion Paper Number 278). Center for European Governance and Economic Development Research. 
Caner A. (2016). Happiness and life satisfaction in turkey in recent years. Social Indicator Research, 127(1), 361399.

Castellanos - Cereceda, R. (2013). Understanding the linkages and possible causal relationships between the provision of basic public services, government performance and subjective wellbeing: the case of Mexico at the subnational level. (Conference Paper). ICPP 2013- 1st International Conference on Public Policy.

Çoban, H. \& Deyneli, F. (2005). Kamuda kalite artırma çabaları ve performansa dayalı bütçeleme. 20. Maliye Sempozyumu Bildiri Kitabı içerisinde (ss. 326-344). Denizli.

Daştan, İ. \& Delice, M.E. (2015). Belediye hizmetlerinden memnuniyet düzeylerini etkileyen faktörlerin değerlendirilmesi: İzmir büyükşehir belediyesi örneği. The Journal of Academic Social Science Studies, 32(1), 203223.

DeHoog,R.T., Lowery D. \& Lyons W.E. (1990). Citizen satisfaction with local governance: a test of individual, jurisdictional, and city-specific explanations. The Journal of Politics, 52(3): 807-837.

Denhardt, R. B., \& Denhardt, J. V. (2000). The new public service: serving rather than steering. Public Administration Review. 60(6), 549-559.

Diagne, M.F., Ringold D. \& Salman Z. (2012). Governance and public service delivery in Europe and Central Asia: unofficial payments, utilization and satisfaction. Policy Research working paper ; no. WPS 5994. Washington, DC: World Bank.

Duffy, B. (2000). Satisfaction and expectations: Attitudes to public services in deprived areas. (CASE Paper No. 45). London School of Economics Centre for Analysis of Social Exclusion.

Eren, V. (2003). Kamu yönetiminde yeni meşruluk temeli olarak müşteri odaklı yönetim yaklaşımı. Ankara Üniversitesi SBF Dergisi, 58 (1), 56-70.

Eren, K. A. (2015). Subjective well-being and determinants of happiness in Turkey: 2004-2013 period. (Yayımlanmamış Yüksek Lisans Tezi). İstanbul tecnik Universitesi, İstanbul.

Farazmand, A. (1997). Institutionalization of the new administrative state role. Conference Paper of 1997 Annual Conference of the American Political Science Assosiation. 28-31 Ağustos 1997, Washington DC.

Ferreira, S., Moro M. \& Clinch J.P. (2006). Valuing the environment using the life-satisfaction approach. (Working Paper). Planning and Environmental Policy Research Series; PEP/06/05. University College Dublin. School of Geography, Planning and Environmental Policy.

Folz, D.H. (1996). Survey research for public administration. Thousand Oaks, CA: Sage Publications.

Frey, B.S., Luechinger, S. \& Stutzer A. (2009). The life satisfaction approach to valuing public goods: The case of terrorism. Public Choice, 138(3-4), 317-345.

Gandelman, N. \& Hernández-Murillo, R. (2012). What do happiness and health satisfaction data tell us about relative risk aversion?. (Discussion Paper, No. 74). Universidad Ort, Uruguay.

Gürsakal S. \& Öngen K.B. (2008). 2007 Yaşam memnuniyeti anketinin istatistiksel yöntemler ile analizi. Uludağ Üniversitesi İktisadi ve İdari Bilimler Fakültesi Dergisi, XXVII(1), 1-14.

Hausman, D. \& McPherson M.S. (1997). Beware of economists bearing advice. Policy Options, 18(7), 16-19.

James, O. (2009) Evaluating the expectations disconfirmation and expectations anchoring approaches to citizen satisfaction with local public services. Journal of Public Administration Research and Theory, 19(1), 107-123.

Jilke, S.R. \& Van de Walle S. (2013). Two-track public services? Citizens voice behavior towards liberalized services in the EU15. Public Management Review, 15(4), 465-476.

Juwaheer, T. D. (2011). Gender bias in hotel guests' perceptions of service quality: an empirical investigation of hotels in Mauritius. e-Review of Tourism Research, 9(5), 164-189.

Kotakorpi K. \& Laamanen J.P. (2007). Welfare state and life satisfaction evidence from public health care. (Working Paper No 07-053/3). University of Tampere Department of Economics, Tinbergen Institute.

Levinson, A. (2009). Valuing public goods using happiness data: the case of air quality. (Working Paper No: 15156). The National Bureau of Economic Research, Cambridge.

Lin, N. P., Chiu, H. C. \& Hsieh Y.C. (2001). Investigating the relationship between service providers' personality and customers' perceptions of service quality across gender. Total Quality Management, 12(1), 57-67. 
Lyons W.E., Lowery D. \& DeHoog R.H. (1992) The politics of dissatisfaction: citizens, services and urban institutions. London: ME Sharpe, 19-45.

Ma, L. (2017). Performance management and citizen satisfaction with the government: evidence from Chinese municipalities. Public Administration. 95(1), 39-59.

Mansor, N. \& Razali C.H.C.M. (2010). Customers' satisfaction towards counter service of local authority in Terengganu, Malaysia. Asian Social Science, 6(8), 32-36.

Michelson E. \& Read B.L. (2011). Public attitudes toward official justice in Beijing and rural China., Margaret Y.K. Woo and Mary E. Gallagher (Der.), Chinese Justice: Civil Dispute Resolution in Contemporary China, içinde (ss. 169-203). Cambridge and New York: Cambridge University Press.

Mill, J. S. (2008). Utilitarianism. 1863 recovered by Jonathan Bennett.Kitchener: Batoche Books.

Miller, T.L. \& Miller, M.A. (1991). Standards of excellence: US residents' evaluations of local government services. Public Administration Review, 51 (6), 503-513.

Millward, B. \& Provan, K.G. (2000). Governing the hollow state. Journal of Public Administration Research and Theory, 10 (2), 359-379.

Mokhlis, S., Aleesa, Y. \& Mamat İ. (2011). Municipal service quality and citizen satisfaction in Southern Thailand. Journal of Public Administration and Governance, 1(1), 122-137.

Montalvo, D. (2009). Citizen satisfaction with municipal services. AmericasBarometer Insights, 18: 1-6.

Morgenson, F.V. (2012). Expectations, disconfirmation, and citizen satisfaction with the US federal government: testing and expanding the model. Journal of Public Administration Research and Theory, 23(2), 289-305.

Muş, E., Köksal, T. \& Yeşilyurt H. (2014). Türkiye'de güvenlik hizmetlerinin vatandaş memnuniyeti açısından değerlendirilmesi. International Journal of Human Sciences, 11(2), 559-581

Ng, Y.K. (2000). Happiness, life satisfaction, or subjective well-being? a measurement and moral philosophical perspective. (Working Paper). Singapore Nanyang Tecnological University.

OECD (2013). Citizen satisfaction with public services in government. OECD Glance 2013 içinde (ss. 1-167), OECD Publishing.

Oliver, R. (1980). A Cognitive model of the antecedents and consequences of satisfaction decisions. Journal of Marketing Research, 17(4), 460-469.

Osborne, D \& Gaebler, T. (1992). Reinventing government: how the entrepreneurial spirit is transforming the public sector. MA: Addison-Wesley

Parasuman, A., Berry L.L. \& Zeithaml V.A. (1990). An empricial examination of relationship in an extended service quality mode. Marketing Science Institute, Cambridge.

Peker, Ö. (1995). Toplam kalite yönetimi ve sürekli iyileştirme. Kamu Yönetimi Disiplini Sempozyumu Bildirileri. Cilt II, TODAİE Yayını, Ankara, 51-70.

Rathgeb, S \& Lipsky, M. (1993). Non-profits for hire: the welfare state in the age of contracting. Cambridge: Harvard University Press.

Robertson, R. \& Ball, R. (2002). Innovation and improvement in the delivery of public services: the use of quality management within local government in Canada. Public Organization Review: A Global Journal, 2 (4), 387-405.

Roch, C. H. \& Poister, T. H. (2006). Citizens, accountability, and service satisfaction. Urban Affairs Review. 41(3), 292-308.

Salinas-Jimenez M., Artes J. \& Salinas-Jimenez J. (2011). Education and satisfaction with life: the role of positional concerns. Social Indicators Research, 103(3), 409-426

Snipes, R. L., Thomson, N. F., \& Oswald S. (2006). Gender bias in customer evaluations of service quality: An empirical investigation. Journal of Service Marketing, 20(4), 274-284

Steinberg H. (2009). State and local governments' use of performance measures to improve service delivery. AGA CPAG Research Series. Report No.23, November 2009

Stipak, B. (1980). Local governments' use of citizen surveys. Public Administration Review, 40 (5), 521-525.

Swan, J.E. \& Trawick F.I (1980). Satisfaction related to predictive vs. desired expectations. H.Keith Hunt ve Ralph L.Day (Der.). 4th Annual conference on cnsumer stifation, dissatisfaction, and complaining behavior içinde (ss. 712). Bloomington, Indiana University. 
Swindell, D. \& Kelly, M. J. (2000). Linking citizen satisfaction data to performance measures: A Preliminary evaluation. Public Productivity and Management Review, 24(1), 30-52

Şimşek, M. (2000). Sorularla toplam kalite yönetimi ve kalite güvence sistemleri. İstanbul: Alfa Yayınları.

Tan, K. C. \& Kek, S. W. (2004). Service quality in higher education using an enhanced SERVQUAL approach. Quality in Higher Education, 10(1), 17-24.

Topcu, Y. (2008). Çiftçilerin tarımsal destekleme politikalarından faydalanma istekliliğinde etkili faktörlerin analizi: Erzurum ili örneği. Akdeniz Üniversitesi Ziraat Fakültesi Dergisi, 21(2), 205-212.

Urmson, J.O. (1953). The interpretation of the moral philosophy of J.S. Mill. The Philosophical Quarterly, 3(10), 3339

Van Praag, B.M.S \& Baarsma, B.E. (2004). Using happiness surveys to value intangibles: the case of airport noise. The Economic Journal, 115(500), 224-246

Van Raaij, W.F. (1989). Economic news, expectations and macro-economic behavior. Journal of Economic Psychology, 10(4), 473-493.

Van Ryzin G.G. (2004). Expectations, performance, and citizen satisfaction with urban services. Journal of Policy Analysis and Management, 23(3), 433-448

Webb, K.W. \& Harry, P.H. (1973). Obtaining citizen feedback: the application of citizen surveys to local governments. Washington DC: Urban Institute

Wilson, A., Zeithaml V., Bitner M.J. \& Gremler D.D. (2008). Services marketing. First European Edition: Mc GramHill Education

Yenice E. (2006). Kamu kesiminde performans ölçümü ve bütçe ilişkisi. Sayıştay Dergisi. 61, 57-68 


\section{Extended Abstract \\ Expectation Anchoring and Expectation Disconfirmation Hypotheses of Judicial Services: The Case of Turkey}

New public policies have been developed to get rid of inefficient state structure which prioritize the structure and form of production more than needs of individuals. Also, it resembles a management method in the form of adapting private sector practices to public sector administration and implements to make public institutions more citizen-centered and more relevant to market conditions. Yet, adaption of the private sector's customer-focused understanding to public sector goals and aims as well as determination at what level these can be reached should be clarified by details. Indeed, for this clarification, reliable and objective measurements are needed. Performance is accepted as one of the good indicator of these measurements in economics literaure since it provides answers to how existing sources should be utilized while achieving predetermined goals and it is a fundamental determinant which regulates both public and private sector organizations. In this respect, in the citizen-oriented policies within the framework of the new public administration approach, performance can be accepted as a delivery bridge of goods and services between today and future in line with the desires and the needs. Ultimately, if the needs of individuals are satisfied by provided goods then the delivery performance of the state or private organization can be evaluated as acceptable. However, if it does not meet the expectations of the individuals, the performance of the presentation is evaluated as negative. So, citizen preferences and demands for the public goods should be determined in order to provide the correct outputs that will satisfy the needs of citizens. That's why, the socio-economic and socio-demographic elements of the individuals and households living in the country where the services are provided should be well defined and the performance elements should be shaped within the framework of these elements. Concordantly, expectation anchoring and expectation disconfirmation hypotheses provide both normative and positive analyzes of the satisfaction of individuals and households from public services and how these level of satisfaction will change in the future.

The determination of this triple interaction relationship between satisfaction, expectation and performance has been achieved through expectation anchoring and expectation disconfirmation hypotheses. According to expectation anchoring hypothesis, there is a negative relationship between the satisfaction and high service provison expectation. In other words, the people who are satisfied today and have high expectations on provision of goods and services are likely to be disappointed in future. Additionaly, according to expectation disconfirmation theory there is a strong and inverse relationship between expectation and performance of public services. More misapprehensions arises in higher expectation level, and so negative disconfirmation occurs. Indeed, positive disconfirmation occurs when provision performance is greater than expectations with pre-acceptances of negative disconfirmation as an indicator of dissatisfaction while not neglecting positive disconfirmation as a sign of satisfaction. The purpose of this study is to test the validity and the accuracy of stated hypotheses for judicial services while the reason of chosing these hypotheses is to understand the mentioned triple relationship for judicial service in Turkey. Specifically the validity of these hypotheses specially in judicial services is investigated since we believe that justice is a good representative in reflecting the general perception/behavior structure of society due to its pure public good chracteristics such as subjecting to collective consumption with non-excludablity as well as nonrivalrous.

The two main hypotheses are sought for judicial services of Turkey can be summarized

as: 
$H_{1,0}:$ Satisfaction minus expectations has a positive relation with satisfaction

$H_{2,0}$ : There is a negative relation between expectations and satisfaction

In this study, aforementioned hypotheses are tested for Turkey by using the public security services' positive propositional micro individual data of TurkStat 2012 Life Satisfaction Survey by employing binary probit regression model. Binary probit model is chosen since it allows the estimation of the result with the maximum likelihood method without the need for classification of the data if dependent variables are structured in two-level clear answers such as exist-non-exist and yes-no. Additively, 2012 data has been selected since it was the last year this survey was conducted at the national level.

The estimated regression model with its functional equation is below:

\begin{tabular}{|c|c|}
\hline For Model 1 & For Model 2 \\
\hline $\begin{array}{l}\mathrm{Y}=\mathrm{PJSS} \rightarrow \mathrm{f}(\mathrm{AGE}, \mathrm{RA}, \mathrm{SEX}, \mathrm{MS}, \mathrm{ED}, \mathrm{EM}, \\
\text { GSLL, HS, SME) }\end{array}$ & $\begin{array}{l}\text { Y }=\text { PJSS } \rightarrow \mathrm{f}(\text { AGE, RA, SEX, MS, ED, EM, } \\
\text { HAM, GSLL, E) }\end{array}$ \\
\hline PJSS = Satisfaction in Public Judicial Services & PJSS $=$ Satisfaction in Public Judicial Services \\
\hline AGE $=$ Age of Public Service User/Citizens & AGE $=$ Age of Public Service User/Citizens \\
\hline $\begin{array}{l}\text { RA = Residential Area (City -RAC or Rural- } \\
\text { RAR) }\end{array}$ & $\begin{array}{l}\text { RA }=\text { Residential Area (City- RAC or Rural - } \\
\text { RAR) }\end{array}$ \\
\hline SEX $=$ Gender $($ Male $-\mathrm{M}$ or Female $-\mathrm{F})$ & SEX $=$ Gender $($ Male $-\mathrm{M}$ or Female $-\mathrm{F})$ \\
\hline $\begin{array}{l}\text { MS = Marital Status (Married - MSM or Single- } \\
\text { MSS) }\end{array}$ & $\begin{array}{l}\text { MS = Marital Status (Married - MSM or Single - } \\
\text { MSS) }\end{array}$ \\
\hline $\mathrm{ED}=$ Education Level (classified in 7 groups) & $\mathrm{ED}=$ Education Level (classified in 7 groups) \\
\hline $\begin{array}{l}\text { EM= Employment (Unemployed- UEM or } \\
\text { Employed - EM) }\end{array}$ & $\begin{array}{l}\text { EM= Employment (Unemployed- UEM or } \\
\text { Employed - EM) }\end{array}$ \\
\hline GSLL $=$ General Satisfaction Level in Life & GSLL $=$ General Satisfaction Level in Life \\
\hline HS = Household Size & HS = Household Size \\
\hline SME $=$ Satisfaction Minus Expectation & $\mathrm{E}=$ Expectation \\
\hline
\end{tabular}

\section{For Model 1}

$P J S S=\beta_{0}+\beta_{1} S M E+\beta_{2} R A C+\beta_{3} S E X M+\beta_{4} A G E+\beta_{5} M S M+\beta_{6} E D+\beta_{7} U E M+\beta_{8} G S L L+\beta_{9} H S+\varepsilon$

For Model 2

$P J S S=\beta_{0}+\beta_{1} E+\beta_{2} R A C+\beta_{3} S E X M+\beta_{4} A G E+\beta_{5} M S M+\beta_{6} E D+\beta_{7} U E M+\beta_{8} G S L L+\beta_{9} H S+\varepsilon$

According to the findings, expectation is the one of the indicatiors of provision performance of public goods such as satisfaction and the both hypotheses have been adapted fully. Besides, the evidences have shown clearly that there is a negative relationship exists between expectation and satisfaction consistent with expectation anchoring theory. Also, satisfaction minus expectation is found to be correlated correctly with performance. Forbye, satisfaction positively correlated with predicted probability value, confirming the hypothesis of expectation disconfirmation. Poor performance expectation leads more judicial service satisfaction and the citizens who are generally happy from their lives are also very satisfied from the presentation of justice. Moreover, this study provided the preference profiles of Turkish justice service users through their service provision satisfactions since it has been found that individuals' expectations of the future as well as their satisfaction level with current public services delivery are directly affected by their socio-demographic and socioeconomic characteristics. 